\title{
The Development of the Tarekat among the Madurese Population until the Beginning of the 20th Century
}

\section{$\underline{\text { Iswahyudi }}$}

Yogyakarta State University, Indonesia

Email: iswahyudi@uny.ac.id

\begin{abstract}
:
In its development, the number of tarekat found in Madura was three, namely the tarekat Qadiriyah, the tarekat Qadiriyah Wa Naqshabandiyah, and the tarekat Tijaniyah. In addition, the tarekat Syatariyah, which had a lot of contact with the traditions of the local Madurese community, had also been influential, even though it was not so big. In this case it is known that starting from the development of the performing arts among the Madurese population called rateb, or from the Arabic language ratib which is similar to the debus performances in Banten and Aceh, there is a strong suspicion that the tarekat Samaniyah has also developed in Madura since the 18th century. In its journey, the popularity of the tarekat Sammaniyah, especially in Madura, was replaced by the Qadariyah wa Naqsabandiyah. This tarekat in its development has replaced the fame of the tarekat Sammaniyah in the archipelago. The description from the sketch shows that in reality, we are often faced with local Islamic sketches, in the form of rituals, such as tarekat, tahlilan, salvation, and so on. The approaches used to telescope this are textual-contextual and structural-functional approaches. From the analysis, it is found that the patterns of understanding and attitudes of the majority of rural communities, especially Madurese, practice Islamic teachings in the form of rituals that are independent, walk alone, without recognizing the relationship between students and sheikhs or murshids.
\end{abstract}

\section{Keywords:}

tarekat; madura; qadiriyah; naqshabandiyah; tijaniyah; sammaniyah

\section{Introduction}

The notion of tarekat is always synonymous with the values of Sufism because it comes from the word thariqah which means the path that must be taken by someone who wants to do Sufism so that he is as close to his God as possible. Tarekat also implies a religious organization which has a shaykh (murshid), a ritual ceremony, and a method of dhikr of its own. As a methodology, tarekat is also called suluk which means a collection of procedures and rules related to parts in Sufism Sufism (Nasution, 1986: 89; Kurnia, 2019: 286287). Meanwhile, according to Ibn Khaldun Sufism is one of the new sharia sciences in Islam. Its origin is the deeds of salaf scholars from the friends, tabi'in, and those after them. The basis of Sufism is to be diligent in worshiping, to decide on a path other than that to Allah, to turn away from the splendor and luxury of the world, to get away from what the majority of humans want, whether in the form of property or position, and isolating oneself from creatures and practicing for worship (Isa, 2010: 13).

The presence of Sufism and its teaching institutions called tarekat is an effort to get closer to God through ways of inner purification and increasing worship. The tarekat movement into the archipelago of course coincided with the presence of Islam. Of the many tarekat around the world, there are only a few tarekat that have entered and developed in the archipelago. This can happen because of the convenience factor in terms of communication in the process of spreading his teachings. These tarekat are those that have been around for a 


\section{Britain International of Humanities and Social Sciences (BIoHS) Journal \\ ISSN: 2685-3868(Online), 2685-1989(Print) \\ Vol. 3, No. 2, June 2021, Page: 291-301}

long time in Mecca and Medina, which at that time became the center of Islamic activity (Trimingham, 1973: 271-281).

There were eight tarekat which entered and developed in the archipelago from the 17th to the 19th century, namely the Qadiriyah, Rifa'iyah, Naqsabandiyah, Satariyah, Samaniyah, Al-Haddad, Khalwatiyah, and Khalidiyah tarekat. However, the number of tarekat from the mention of the names of the tarekat is actually only six because the Khalwatiyah tarekat and the Khalidiyah tarekat are basically from the Naqsabandiyah tarekat which later in its development split into two streams (Said, 1982: 274).

Of a number of tarekat that have developed in the archipelago, there are several tarekat whose existence is difficult to prove. These tarekat are Rifaiyah, Samaniyah, and AlHaddad. Especially for the Al-Hadad tarekat or often called Haddadiyah, it is a tarekat whose emergence is due to the creativity of the teachings brought by the Arab descendants of the archipelago (Thohir, 2002: 28). Of the several existing tarekat, it is at least known about the first person who played a role in its spread, such as the Qadiriyah Starekat which was brought to the archipelago for the first time by Sheikh Hamzah Fansuri and this tarekat seems to have been developing in Indonesia until the 20th century (Al-Attas, 1966: 43). Then related to the Rifaiyah order is a departure from the life history of Nuruddin Ar-Raniry who had studied with Basyaiban in Gujarat. He was later appointed caliph in the tarekat and subsequently gained the trust to spread to the Aceh area. Likewise with the Satariyah order, whose arrival in the archipelago was brought by Abdurr Rauf As-Singkili. Until now his followers still have a big influence in Ulakan, West Sumatra because it was developed here by his student Syeikh Burhanuddin. Besides that, the teachings of this tarekat are also found in Takeran, Nganjuk, East Java (Dhofier, 1982: 142).

In the next development, in the 1850s something new happened because of the merging of the two tarekat into one, namely the Qadiriyah order and the Naqshabandiyah order to become the Qadiriyah-Naqshabandiyah order. This tarekat was first introduced by the creativity of a Sufi from Kalimantan, namely Syeikh Ahmad Khatib Sambasi, who had previously lived in Makkah (Nasution, 1990: 82). With the merger of the QadiriyahNaqshabandiyah tarekat, both of them can integrate by complementing each other in delivering a person to his spiritual attainment because morally, this tarekat can guide the balance of worship and form a collective awareness for its followers.

\section{Research Methods}

This research is a case study that relies on historical studies. Therefore, to find out about the development of the tarekat among the Madurese population, it is carried out using historical methods or historical research methods. In this sense it can be interpreted as a systematic collection of principles and rules intended to help effectively collect material sources from history, in assessing or analyzing them, critical sources, and presents a "synthesis" of the results achieved. This method is qualitative in the form of literature study using written sources from the library collection in the form of books, journals, and other printed sources (Garraghan, 1957: 33).

Because the object in this study is about the various tarekat that existed among the Madurese population and existed until the early 20th century, of course, it is also seen about the dynamics and their role in the formation of Islamic religious values among the Madurese population. Primary and secondary data collection techniques are carried out through research 
libraries which are carried out by visiting various libraries and agencies that store reference books, articles in magazines and newspapers such as the National Library of the Republic in Indonesia and in the libraries of various universities and Islamic Institutes as well as in various Islamic boarding schools in Indonesia. Madura and East Java. After the search for written material has been completed, the next step is to select and verify the data and compile it into a writing (Iswahyudi, 2020: 800).

\section{Results and Discussions}

\subsection{The Existence of the Tarekat in Madura}

The existence of tarekat in its development in Madura consists of three tarekat, namely Qadiriyah, Qadiriyah Wa Naqshabandiyah, and Tijaniyah. In addition, based on Schrieke's conjecture, the Syatariyah tarekat, which had a lot of contact with the traditions of the local Madurese community, had also been influential, although not so much (Bruinessen, 2012: 422). In this case Bouvier also said that starting from the development of the performing arts among the Madurese population called rateb, or from the Arabic language ratib which has similarities with the debus performances in Banten and Aceh, there is a strong suspicion that the Samaniyah tarekat has also developed in Madura since the 18th century. (Bouvier, 1989: 219). In its journey, the popularity of the Sammaniyah tarekat, especially in Madura, was replaced by the Qadiriyah wa Naqsabandiyah tarekat. This tarekat is a combination of several mediation techniques between the two tarekat, such as the sirri dhikr which is the hallmark of the Naqsabandiyah tarekat and the loud dzikir which is characteristic of the Qadariyah tarekat. This tarekat was propagated to Indonesia by Ahmad Khatib al-Sambasi who lived and taught in Mecca in the mid-19th century. This tarekat in its development has replaced the fame of the Sammaniyah tarekat in the archipelago. One of the caliphs appointed by Ahmad Khotib as his successor was Abdul Karim from Banten, a figure who was often associated in colonial literature with the Banten rebellion (Bruinessen, 2012: 426).

The tarekat Qadiriyah is the teaching of the tarekat founded by Abd al-Qadir Jailani or known as Shaykh Abd al-Qadir Jilani al-gwats or qutb al-awiliya. He also obtained the title Muhyiddin or religious generator. It is said that he got this title because Shaykh Abd al Qadir al Jilani was able to heal a sick person who was by the side of the road. After he gave food and drink to a person who was sick, he immediately looked fresh and healthy so that he was always given praise and the title Muhyiddin which means a person who "can revive religion" (Schimmel, 1986: 253). This tarekat occupies a very important position in the history of Islamic spirituality because it has not only played a role as a pioneer in the birth of various other tarekat organizations but also as a forerunner to the emergence of various branches of tarekat in the Islamic world. Syaijkh Abd al-Qadir died in Baghdad in $561 \mathrm{H}$ or 1166 AD. (Bruinessen, 2912: 259).

The tarekat Qadiriyah in Madura is thought to have experienced much earlier development compared to other tarekat although there are no clear instructions or even still being spread in secret (Wirjoasmoro, 1926: 252). The spread of the tarekat Qadiriyah to the Madura region at the first time was brought by a student of the great scholar Khatib Ahkmad Sambas who came from the island of Madura, namely Syekh Abdadmuki (Al-Attas, 1963: 35,53). This is reinforced by the strong tradition of the feast held on every Friday night until now which is actually in the context of commemorating Abd al Qadir Jailani (Kuntowijoyo, 2002: 332). The tarekat Naqsyabandiyah which also developed in the Madura region had no relationship with this tarekat which was in Java, so that the Madurese community preferred the tarekat Naqsabandiyah Muzhariyah. This tarekat first developed in the Madura area brought by Kyai Abdul Azim Bangkalan who had lived in Mecca for a long time and there he 
became the caliph of Muhammad Salih who at that time often taught the teachings of the tarekat to Madurese people who were performing the pilgrimage (Bruinessen, 1992: 176). What is interesting about the tarekat Naqsyabandiyah Muziriyah in Madura is that the mursyid are composed of women and this is not found in other areas.

The tarekat Qadiriyah Wa Naqsabandiyah is a tarekat which is a combination of the tarekat Qadiriyah and Naqsabandiyah (TQN). This tarekat is most likely originating from the archipelago itself. This tarekat was founded by Ahmad Khatib ibn Abd Al-Ghafar Sambas in the mid-19th century living in Makkah. The teachings of the tarekat contained in the book of Fath al-Arifin were passed down to his students, including Ma'ruf al-Palimbani and Abd alRahim al-Bali. After Ahmad Khatib Sambas died in 1878, the position of the tarekat leadership was replaced by its caliph named Shaykh Abdul Karim Banten (Sujuthi, 2001: 54).

The tarekat Qadiriyah Wa Naqsabandiyah has also developed in Madura since the 1920s. A caliph from Shaykh Sambas who came from Madura named Ahmad Hasbullah bin Muhammad has succeeded in developing this tarekat among the Madurese community. In an interview conducted with one of the sons of Kyai Kholil Bangkalan, Kyai Haji Abdullah Sahal, it was found that many of the leaders of the tarekat Qadiriyah wa Naqsabandiyah studied from his father and then they also received some kind of certificate (Mulyati et al., 2004: 260). The fame of Kyai Kholil Bangkalan although there are no sources that clearly mention him as a follower of the teachings of the tarekat Qardriyah wa Naqsabandiyah but there is a strong suspicion that he was indeed in this tarekat. This was reinforced by his experience studying tassawuf, Arabic grammar, and figh to Shaykh Nawawi Banten, Shaykh Abd al Karim Banten, and Shaykh Mahfud Termas, who later led him to his spiritual achievements and always appeared to be mentioned that Kyai Kholil Bangkalan was a tarekat expert and also considered as someone who is sacred (Zulkifli, 2002: 26).

The tarekat Tijaniyah was founded by Shaykh Abas Ahmad Al-Tijani who was the son of Muhammad bin Muhtar and lived in Ain Madi, southern Algeria. The name Tijani is taken from his mother's surname. Since he was a child, Shaykh Abas Ahmad Al-Tijani has had special signs that show that he will become a great man. Armed with memorizing the Koran and at the same time being diligent in seeking good knowledge of ushul, furu, and adab, at the age of 16 he continued to seek knowledge outside the region, including in the Abyad area in $1176 \mathrm{H}$, in Telemsan in $1181 \mathrm{H}$, and performed the pilgrimage in Makkah in $1186 \mathrm{H}$. After staying for some time in Mecca and Medina, he then continued his journey to seek knowledge to Cairo and there he also stayed for some time (Fathullah. 1985: 64).

The tarekat Tijaniyah entered the archipelago in 1921 by Kyai Anas Buntet from Cirebon. He is a student of Shaykh Alfa Hasyim and Shaykh Ali bin Abd. Allah Al-Thayib in Medina. According to Bruinissen, the tarekat Tijaniyah that entered Madura did not come through West Java but directly from Arabia. Kyai Jauhari and Kyai Khozin from Madura who studied in Mecca at one point while there performed baiah tarekat Tijaniyah and then they were appointed muqaddam. After returning to Madura around the 1930s they both began to teach the teachings of the tarekat. Kyai Jauhari then succeeded his father to lead a pesantren in the Prenduan area, while Kyai Khozin taught tarekat in the Beladu Probolinggo area. With the circulation of rumors regarding the issue of conflict related to the tarekat Tijaniyah in Cirebon, Kyai Jauhari and Kyai Khozin were more careful in teaching the tarekat so that they did not face many problems. In its development, Kyai Jauhari inherited his position as the leader of the pesantren to his son named Kyai Tijani and under his leadership the pesantren in Prenduan could develop into a large boarding school (Bruinessen, 2012: 441-443). 


\subsection{The Teachings of the Tarekat and the Widening System}

Starting from the development of his teachings, Sufism is one of the alternatives most widely adopted by people in Madura. In this case Muhammad Abdullah managed to find more than two hundred manuscripts on the island of Madura, namely in Bangkalan, Sampang, Sumenep, and Pamekasan. Most of these texts contain theological teachings, fiqh, commentary, and Sufism. One of these manuscripts, the Tuhfah Al-Mursalah manuscripts or Wahdat-Al-Wujud or Martabat Tujuh, was found by him at the Az-Zubeir Islamic boarding school in Pamekasan.

The teaching of Martabat Tujuh studies the essence of God through its manifestation or is called tajjali, starting from the manifestation of the universe to all its contents, including humans. The first tajjali is the ahadiyah dignity or called lả-ta'yun which means that it is still in absolute form and cannot be recognized by its essence because it is still quiet from all its characteristics, supports and relationships with others. Ahadiyah is the transcendent oneness or the highest oneness, $\mathrm{He}$ is kunhihaq which is silent from nature, color, appearance and name.

The second dignity is wahdah, or called ta'yun early which means the beginning of reality. In this dignity, everything is still in an outline condition and there is no separation and differences so that everything is a unity that contains plurality. This is the reality of Muhammad which is still hidden in the secret of Allah. Wahdah's dignity is called the Essence of Muhammad or Nur Muhammad, which is like God's knowledge of the essence, nature, name, and all realities without any separation from one another because it is an initial reality.

The third tajjali of God is the dignity of wahidiyah, namely the second ta'yun, which is when Allah wants to create something through essence, nature, asthma and everything that is manifest by means of munfasil or something that has been separated from one another. Everything that will be created has clear boundaries but is not yet dhair and is called a'yan aabitah. This stage is the unfolding of His attributes and names. In this dignity which is called tajalli substance, that which is efficacious, tajalli through its nature and name. With this, the essence is called Allah who is the collector or binder of the most perfect attributes and names or Asmaul-Husna, but the nature of the name is not identical to the Essence of Allah on the one hand.

The fourth tajjali is called the realm of spirits. This dignity is an aspect of birth that is still in its mujarrad and pure form. This dignity teaches that in the beginning God created all animate beings in the form of subtle bodies or lamifes. As a subtle soul, this spirit realm cannot be known by the five dhahir senses or sight, hearing, smell, taste, touch, and mind. The spirit realm is the beginning of Allah's creation of the ideal spirit and all that will be created. The first spirit created by Allah is the spirit of the prophet Muhammad, as said by the prophet: "aw (w) alu mậlkhalaqa ruh" which means that the first spirit created is the spirit of idafi, namely the spirit of the prophet Muhammad.

The fifth tajjali is the dignity of the mitsal realm. In this dignity the stages are already in the form of a subtle structure and cannot be divided and separated by the physical senses but can be lived out by the mental senses. Then after the classification occurs, the spirit realm will descend into the mishal realm which is called the malakut realm. In this realm, what is the boundary between the world of the soul and the causal or causal relationship does not contain matter but in the form of dimensions marked with various colors. 
Furthermore, the sixth tajalli is the dignity of the ajsam realm. This dignity begins when Allah wills to create the body and infuse life into the body. All of these lives have their respective types, including the human body, the body of the jinn and the body of the devil. It is in this dignity that Allah engages in the realities of His names and attributes. In his actual form Allah begins to manifest his name and attributes of greatness and majesty through nature. Then from nature will emerge living things, plants and animals.

The seventh dignity is the dignity of our human beings. This dignity includes all dignity above it, namely the three dignity of an inner nature, namely; ahadiyah, wahdah, wahidiyah and three dignity that are born, namely the spirit realm, the mitsal realm, and the ajsam realm. This dignity is called the hijab which means the curtain that separates the eyes of the human heart and the Essence of Allah. When this veil is open, then the human heart will immediately receive the light of Allah and immediately transcend the Essence of God. Perfect humans or human beings emit the Divine to become real. Human beings are a reflection of Allah because Allah has promised not to show His essence except to selected humans who in this case have received His guidance (Abdullah, 2013: 191-196).

Then related to other teachings, it seems that the tarekat Naqsabandiyah is one of the dominant tarekat even though the number of followers is not that large. It was also stated that the teachings of this tarekat in Madura were oriented towards merging with the Shari'a and also culturing the guardian who was its lord, Abd Al-Qadir Al Jilani. The tarekat Naqsabandiyah when viewed from one of its teachings is that it can be categorized as a Sufism tarekat. Included in this teaching are the suluk tradition, which is traditionally still taking place in Payudan cave, Guluk-guluk, Sumenep Regency. In the suluk that is believed by the followers of the tarekat Naqsabandiyah is based on the Tanwirul Qulub which consists of 19 conditions (Bruinessen, 2012: 441-443). The conditions are consecutively: 1. Intend to be ihklas, not happy and summah (splendor) both physically and spiritually. 2. Asking permission to pray from the Shaykh, may not enter suluk without his permission as long as it is still under supervision and education (for people who have teachers). 3. Uzlah (seclusion), getting used to not sleeping much and being hungry and dhikr before suluk. 4. Entering the place of suluk by stepping the right foot and asking Allah for protection from the temptations of Satan and reciting basmallah and surah An-Nas three times. 5. Always perform ablution. 6. It is not allowed to aspire to something sacred. 7. Not allowed to lean back against the wall. 8. Continuously imagining the teacher's visualization. 9. Fasting. 10. Silence unless doing dzikrullah. 11. Stay alert to the four enemies, namely the world, lust, Satan, and lust. 12. Keep away from sound distractions. 13. Keep maintaining Friday prayers and congregations because it aims to obey the prophet. 14. If forced to leave, should cover head to neck and look down. 15. Not sleeping, 16. Keeping the middle of hunger and full, 17. Not allowed to open the door to those who ask him a blessing. 18. All favors that are obtained must be considered as coming from the shaykh, while the shaykh comes from the Prophet. 19. Ignoring vibrations and trajectories in the heart, both bad and good, because this is considered something that can break the heart of the unity of dhikr. The suluk performed in Payudan's ascetic cave is unique in that it does not have a murshid or guiding teacher and also does not have a specific wazifa number. Basically those who perform suluk rituals based on their belief to do austerities only because of a heart call.

Related to the teachings of the tarekat Naqsabandiyah Muzhariyah in Madura, a unique development occurred because it was famous for the appearance of four female disciples (murshidah), namely Nyi Aisyah, Nyi Tobibah, Syarifah Fatimah, and Nyi Syafiah. As it is known that the one who took Nyi Aisyah was Kyai Abdul Azim Bangkalan, the leader of the tarekat Naqsabandiyan Muzhariyah to Madura and was assigned the task of leading and 
serving female followers in the Bangkalan region and especially in elderly congregations. In this case, Nyi Asyah did not hesitate to invite her followers to always live closer to Allah and continuously perform riyadah or dhikr in order to get His pleasure. Then Nyi Tobibah who took took took the role of his direct teacher, Kyai Haji Ali Wafa and got a special assignment to teach in the Ambunten area, Pamekasan. Then Syarifah Fatimah, one of the murshidah of Arab descent, named Habib Muhammad, received allegiance from his two teachers, namely Kyai Sirajudin and Kyai Haji Samsudin. Syarifah Fatimah was assigned to give tawajjuh in the Sumenep area and even to West Kalimantan and Malang, south of East Java. Then for Nyi Syafi'ah, it is getting a pledge from her teacher as well as her own husband, namely Kyai Haji Abdul Wahid Khudzaifah (Mulyati et al., 2014: 99-100).

The teachings of the tarekat Tijaniyah are closely related to Kyai Haji Anas, who while living in Medina had been the talqin of Syakh Allfa Hasyim. After returning to his homeland, Kyai Haji Anas lived in Buntet, Cirebon and in this place he gained the confidence to teach the holy books of the main teachings of the tarekat Tijaniyah, namely the books of Jawahir alMa'ani, Bugyah al-Mustafid, and Munyah al-Murid. The tarekat Tijaniyah in Buntet Cirebon then spread to the east and even reached Madura through Kyai Haji Tijani Jumhur (Ensiklopedi, 1995: 103: Mulyati et al., 2014: 226).

In this case Pijper once summarized the teachings of the tarekat Tijaniyah which allegedly applied both to Java and Madura. The teachings of the tarekat Tijaniyah that must be adhered to include simple practice consisting of wazifa twice a day. One wazifa every day and one special haylalah on Fridays. The wazifa consists of saying astaghfirullah 100 times, saying hello to the Prophet (Allahumma salli'ala sayyidina Muhammad wa'ala alihi) 100 times. This wazifa is pronounced in the morning and evening (after the Fajr and Asr prayers until Isha). The wazifah consists of reciting istighfar 30 times, salawat of the Prophet 50 times, tahlil 100 times, and the Jauharatul kamal prayer 12 times. Wazifa is done once a day and night and is done at night. Haylalah (tahlil) performed on Friday consists of dhikr "la ilaha illalah" or "Allahu-allalhu", both of which are not determined in number. The time to carry it out after Asar prayer until sunset. The conditions for doing this exercise are stipulated, for example, the bandan, clothes and place must be clean. His awrah must be closed, pronounce the intention and face the Qibla and imagine the founder of the tarekat when the student asks for his help and must understand the words he is saying (Pijper, 1987: 85).

According to Bruinessen, the tarekat Sammaniyah is thought to have existed since the end of the 18th century in Madura. It's just that data has not been found who disseminate and show no significant development, so the tarekat Sammaniyah is categorized as one of the local tarekat in Madura. The tarekat Sammaniyah was founded by Muhammad bin 'Abd-al-Karim al-Madani al-Syafii al-Saman in 1718 - 1775 AD and was born in Medina, as a Quraish family. Among his students and followers, he was better known as al-Sammani or Muhammad Samman.

The tarekat Sammaniyah was the first to gain a large following in the archipelago. This congregation is very popular, especially in South Sumatra and Kalimantan (Bruinessen, 2012: 369). Helene Bouvier noted, that this tarekat became known in Java around the end of the 18th century and the beginning of the 19th century. Furthermore, Bouvier explained, in some parts of the island of Madura in that century there was a very popular entertainment, namely Samman, which came from the Sufi ritual of the Sammaniyah order as found in Aceh and Banten (Bouvier, 2003: 219). The popular performances called Ratep Samman probably originated from the tarekat Sammaniyah that was popular in the archipelago in the late 18th and early 19th centuries). Until now, the Samman tradition still exists in several areas in Madura, although its frequency has started to decrease (Bouvier, 2003: 217). 
The Samman tradition, in the view of the Madurese community, is a traditional Islamic art form that puts forward three main aspects in its implementation process, namely aspects of reading, movement, and formation (Rifai, 2005: 42). In fact, in the view of some Madurese kiai, this tradition is seen as part of the tarekat, because the Samman ritual procession and the basic idea of its reading contain praise to Allah (tauhid sentence). Besides containing aesthetic elements, this tradition also contains religious values (Hidayat, 2007: 119). When these readings and movements are practiced, contemplated and enjoyed, they will bring inner pleasure to the practitioner, so that the practitioner or the practitioner will reach the peak that a Sufi or tarekat practitioner wants to achieve, namely closeness to the Creator. Effective media reach the peak through the activity of dhikr until it dissolves in a religious disclosure situation, a silent atmosphere, namely the meeting between God and humans, which in Sufism is commonly called ektase or fana. This religious disclosure situation can only be felt by intuition or inner feelings (Nicholson, 1975: 62).

Samman as a tradition will be space and time. As indicated by Helene Bouvier, that Samman became known to the Madurese along with the spread of tarekat on the island of Java around the 19th century (Bouvier, 2003: 219). Therefore, to fully understand this tradition can be understood with a historical approach. The other side of Samman in the process includes readings and movements, which have their own meaning. To understand the meaning of the reading and the movement, it is necessary to approach it with a phenomenological perspective of religion (Purwadaksi, 2004: 42). If the Samman ratib can be used as an indication of the development of the Sammaniyah tarekat, then related in Madura according to Wahyudin is still being performed in Tlontoraja and Batu Kerbuy villages in Pamekasan district which uses musical accompaniment, while those at Nurul Kholil Bangkalan Islamic Boarding School do not use musical accompaniment (Wahyudin, 2011; Hidayat, 2007).

Starting with the teachings of the Sammaniyah tarekat in Madura, it is possible to link it with the recitation of the Ratib prayer and the samman ritual dzikir, especially those performed in Tlontoraja and Batu Kerbuy villages, Pasean District, Pamekasan Regency. According to Wahyudin, when viewed from the procession of reading the ratib and dzikir this Samman ritual begins with the reading of the Prophet's prayer readings and then continues to read the ratib and dzikir Samman. In the recitation, there are six rounds of recitation, and each round from the beginning to the end of the recitation of the dzikir is not the same even though it has been arranged according to the order. This is because in the reading of the ratib led by chairman Samman there are several that are always repeated for the next round.

The basic idea of recitation of Samman mostly contains dhikr to Allah Swt. The dzikir is said out loud while accompanied by sounds. One of the features of the tarekat Samman in dhikr is that the phrase "la ila ha illa Allah" is sung and then changes to the reading $\mathrm{Hu}, \mathrm{Hu}$, Hu which means He, Dia, Dia (Allah) (Nasution, 1992: 842). The Samman reading, in addition to the basic reading, is also accompanied by other readings that accompany and are sung. The readings that are sung as an accompaniment to Samman's basic reading, consisting of Salawat Burdah, as well as Madurese poetic songs which mean warnings or invitations and stories, can be classified as follows (Hasan, 2017: 120-121):

Examples of meaningful verses of invitation are as follows:

"nyara taretan pad abhakte

nyare sangona bile pon mate

bile pon mate sabe' ka kobhur

ta' andhi' senneng ta' andhi' lebur

tape mon pojhur senneng talebet 
lamon e dhunnya bhejeng atobhet se nyama tobhet maca istighfar sadhejeh dhusa nyo'ona lebbher".

Meaning:

"Let brothers be equally devoted looking for provisions to die if it dies, it is put in the grave have no fun and happiness but if you are lucky it is very happy if in the world diligently repent repentance read istighfar all sins may be forgiven (erased) "

\section{Conclusion}

In the history of Islam in Madura as in other areas in Indonesia, it has a religious style called Sufism, which is a popular term for mysticism in Islam which Western orientalists call Sufism. Sufism or Sufism is actually a form of spiritual life in Islam that aims to have a direct and conscious relationship with God, so that one is fully aware that a person is in God's presence. In general, in the process of Islamization in Indonesia, Sufism is an important channel among other channels of Islamization.

In general, tarekat can gain followers and develop in Madura, of course, apart from being a way of approaching God, it is also because the people here have long been concerned about having supernatural abilities, such as supernatural powers, immunity, superiority, kanuragan and all other occult arts. Thus, they can accept and welcome the tarekat taught by the scholars because it is considered as a new way to have and develop supernatural powers.

Schrieke, who investigated the same subject, said that the Qadiriyah (possibly meaning Qadiriyah wa Naqsyabandiyah) had 'very large' followers and the Naqshbandiyah followers, while the Syattariyah - a tarekat which always conformed to local traditions and beliefs - also boasted in Madura, although not very much. Lots. The current situation, at first glance, seems to reflect a shift towards a more rigorous orthodoxy. The Naqshbandiyah, especially the branch that spread to Madura, was known to be more shari ah oriented than most of the other tarekat, and the Tijaniyah, although often criticized for certain controversial beliefs, shared many similarities in practice with the Islamic reformist movement.

Both the Naqsyabandiyah and Qadiriyah wa Naqsyabandiyah first entered Madura around the turn of the century; The Tijaniyah came a few decades later. It could be that Qadiriyah has been in Madura before. At least, like in many parts of the archipelago, there was an established saint Guru patronage somewhere in Madura or Madurese in East Java, but otherwise it would not have many followers. The influence of Shattari's mystical ideas can live on as this tarekat gradually merges into the popular Madurese mystical-magical practice complex, but anything specific to Shattari's spirituality may be difficult to separate from the whole complex. Yet another tarekat seems to have left its mark in Madurese popular culture, even though it does not exist as a distinct brotherhood among Madurese today (if it is). 


\section{References}

Azra, Azyumardi (2005), Jaringan Ulama Timur Tengah dan Kepulauan AbadXVII \& XVIII. Jakarta: Kencana.

Abdullah, Muhammad (2013), "Eksistensi Martabat Tujuh Dalam Naskah Madura" dalam Meta Sastra, Vol 5, No. 2 Jurnal Penelitian Sastra Vol 5, No. 2 Bandung: Balai Bahasa Jawa Barat, hlm. 191-196

Al-Attas, Syed Muhammad Naquib (1966), Raniry and Wujudiyah of 17th Century .Singapore: MBRAS

Al-Attas, Syed Muhammad Naquib (1963), Some Aspects of Sufism as Understood and Practiced Among Malays. Singapore

Bouvier, Hẽlenẽ (1989),'Musik dan seni pertunjukan di kabupaten Sumenep", dalam Huub de Jonge (ed), Agama, kebudayaan dan ekonomi, Jakarta: Rajawali

Bruinissen, Martin van (1990), "The Origins and Development of the Naqsyabandi Order in Indonesia", dalam Der Islam, no. 67, Vol. 1

Bruinessen, Martin van (2012), Kitab Kuning Pesantren dan Tarekat.Yogyakarta: Gading Publishing

Bruinessen, Martin van (1995),Tarekat and tarekat teachers in Madurese society. in: Kees van Dijk, Huub de Jonge \& Elly Touwen-Bouwsma (eds.), Across Madura Strait: The dynamics of an insular society. Leiden: KITLV Press

Bruinessen, Martin van (1992), Tarekat Naqsyabandiyah Di Indonesia: Survey Historis, Geografis, dan Sosiologis. Bandung: Penerbit Mizan

Bruinessen, Martin van (1989), "Tarekat Qadiriyah dan Ilmu Syeikh Abdul Qadir Jilani Di India, Kurdistan, dan Indonesia": in Ulumul Qur'an, vol 2. No.2

Dhofier, Zamaksyari (1982), Tradisi Pesantren: Studi Tentang Pandangan Hidup Kiai. Jakarta: LP3ES

Ensiklopedi Islam jilid V (1995), Jakarta: Ichtiar Baru Van Hoeve

Fathullah, Fauzan (1985), Biografi Saiyidul Awliyaa Syeikh Ahmad Attijaniy dan Thariqatnya Attijaniyah. Madura: Bintang Samudera

Hafil, Ach. Shodiqil (2016), Komunikasi Agama dan Budaya (Studi atas Budaya Kompolan Sabellesen Berdhikir Tarekat Qadiriyah Naqshabandiyah di Bluto Sumenep Madura). al-Balagh Jurnal Dakwah dan Komunikasi, Vol. 1 No.2, Juli-Desember 2016

Hasan,Nor (2017), Makna dan fungsi tradisi Samman. Ibda Jurnal Kebudayaan Islam Vol. 15, No.1 Mei 2017, p. 122-134

Hidayat, Ainurrahman (2007), "Dimensi Epistemologis Tradisi Ritual Samman Dalam Masyarakat Madura: Telaah Dalam Perspektif Epistemologi 'Abd al-Jabbar', dalam Karsa Jurnal Budaya dan Sosial, Vol.XII no. 2 Oktober 2007. Pamekasan : STAIN

Isa, Abdul Qadir. Hakekat Tasawuf. Jakarta: Qisthi Press, 2010, 13).

Iswahyudi (2020), Toward Remediation of Indonesian New Fine Arts. Britain International of Linguistics, Arts and Education (BIoLAE) Journal Vol. 2, No. 3, November 2020 : 797-809 DOI: https://doi.org/10.33258/biolae.v2i3.332

Jailani, Imam Amrusi (2010), Tarekat "Semi Mandiri": Prototipe Ritual Masyarakat Pedesaan Madura. Ulumuna, Volume XIV Nomor 2 Desember 2010

Kuntowijoyo (2002),Perubahan Sosial Dalam Masyarakat Agraris Madura 1850-1940. Yogyakarta: Matabangsa

Kurnia, Rusdi (2019), Sheikh Muhammad Wali Al-Khalidi's Idea about the education concepts of Tazkiyatun Nafsi. Budapest International Research and Critics Institute-Journal (BIRCI Journal) Vol.2 No.1, february 2019, p. 284-292

Lekkerkerker, C. 'Enkele opmerkingen over sporen van Shamanisme bij de Madoerezen en Javanen' ,Tijdschrift voor Indische Taal-, Land-, en Volkenkunde Deel XLV, Batavia, Albrecht \&Co, $\bullet 1902$ 
Malinowski, B. (1972), "The Role of Magic and Religion”, dalam Lessa \& Vogt, Reader in Comparative Religion: An Anthropological Approach. New York: Harper \& Row Publisher

Mansur, H.M. Laily (1995), Ajaran dan Teladan Para Sufi .Jakarta: Srigunting

Mulyadi, Achmad, "Aspek Feminitas Dalam Tarekat Naqsyabandiyah Muzhariyah Di Madura" dalam STAIN Pamekasan.

Mufid, Ahmad Syafii (2006), Tangklukan, Abangan, dan Tarekat: Kebangkitan Agama di Jawa. Jakarta: Yayasan Obor Indonesia

Mulyati, Sri et.al (2004), Mengenal dan Memahami Tarekat-Tarekat Muktabarah Di Indonesia. Jakarta: Prenada Media Group

Nasution, Harun ed. (1990), Thoriqot Qodiriyyah-Naqsyabandiyah. Tasikmalaya: IAILM

Nasir, Muh. S (2011), Perkembangan Tarekat dalam lintasan Sejarah Islam di Indonesia. Jurnal Adabiyah Vol. 11 Nomor 1, p.113-126

Nasution, Harun, dkk. (1992), Ensikolopedi Islam Indonesia. Jakarta: Djambatan

Nasution, Harun (1986), Islam Ditinjau dari Berbagai Aspeknya, Jilid II. Jakarta: UI Press, 1986

Pijper, G.F. (1987), Fragmenta Islamica: Beberapa Studi Mengenai Sejarah Islam di Indonesia Awal Abad XX, Translated by Tudjimah. Jakarta: Penerbit Universitas Indonesia

Pribadi, Yanwar (2013/1434 H), Religious Networks in Madura: Pesantren, Nahdlatul Ulama and Kiai as the Core of Santri Culture. Al-Jami'ah, Vol. 51, No. 1

Purwadaksi, Ahmad (2004), Ratib Samman dan Hikayat Syekh Muhammad Saman: Suntingan Naskah dan Kajian Teks. Jakarta: PT Kresna Prima Persada

Said, Usman ed. (1982), Pengantar Ilmu Tasawuf. Medan: Proyek Pembinaan Perguruan Tinggi Agama Islam IAIN Sumatra Utara

Schimmel, Annemarie (1986), Dimensi Mistik Dalam Islam, Translated by Sapardi Djoko Damono, et.al, Jakarta: Pustaka Firdaus

Sujuthi, Mahmud (2001), Politik Tarekat Qadiriyah wa Naqsyabandiyah: Studi Tentang Hubungan Agama, Negara, dan Masyarakat. Yogyakarta: Galang Press

Syaifurrahman (2009), Tradisi Suluk di Gua Pertapan Payudan, Daleman, Sumenep Madura , Unpublished thesis the Department of Islamic History and Culture, Fakultas Adab dan Ilmu Budaya, UIN Sunan Kalijaga Yogyakarta

Thohir, Ajid (2002), Gerakan Politik Kaum Tarekat: Telaah Historis Gerakan Politik Anti Kolonialisme Tarekat Qadiriyah- Naqsyabandiyah di Pulau Jawa. Bandung: Pustaka Hidayah

Trimingham, J.S. (1973), The Sufi Orders in Islam .Oxford University Press

Wahyudin (2011), Ratib Samman Di Madura,Unpublished thesis the Faculty of Philosophy UGM

Wirjoasmoro (1926), "Iets over de 'Adat " der Madoerezen”, Djawa VI

Zulkifli (2002), Sufism in Java: the Role of the Pesantren in the Maintenance of Sufism in Java. Jakarta: INIS 